\title{
Disturbance and gap formation in a marine benthic mosaic: influence of shifting macroalgal patches on seagrass structure and mobile invertebrates
}

\author{
Jeff G. Holmquist* \\ Department of Biological Science, Florida State University, Tallahassee, Florida 32306-2043, USA
}

\begin{abstract}
A field experiment was used to examine the interactions among structurally complex, spatially shifting structure (macroalgae deposited by currents), less-complex stationary structure (seagrass), and mobile benthic invertebrates. I tested the effect of drift algal patches on underlying seagrass structure and fauna by establishing manipulated algal mats over seagrass for comparison with control seagrass plots. Control and experimental plots did not differ significantly for any variable prior to algal addition, but most seagrass structure was removed by this disturbance over a 6 mo period. In contrast, abundance of mobile fauna on experimental plots increased after 6 mo of algal cover relative to abundance on control plots. There was also greater evenness in the canopy fauna of the algal plots which contrasted with the high level of dominance apparent on control plots. Although the structurally complex mats formed by drifting algae provided short-term habitat enhancement for some fauna, longterm effects on fauna are probably negative due to mat ephemerality and degradation of seagrass.
\end{abstract}

KEY WORDS: Disturbance - Gap - Structural complexity - Macroalgae - Drift algae - Seagrass · Laurencia spp. Thalassia testudinum - Caridea - Anomura - Brachyura - Mollusca - Ophiuroidea

\section{INTRODUCTION}

Work on the interaction of mobile animals with habitat structure (e.g. Wiens et al. 1985, Stamps et al. 1987 , Wiens 1992, Ims 1995) emphasizes stationary, albeit slowly changing, mosaics. However, in some systems, portions of the mosaic are not spatially fixed (Forman 1995). I report on field manipulations used to examine the interactions among structurally complex, spatially shifting patches (drifting macroalgae), less-complex stationary structure (seagrass), and mobile benthic fauna.

Drift macroalgae do not comprise static, homogeneous structure. These algae often shift position in response to water motion (e.g. Williams Cowper 1978, Holmquist 1994, Bell et al. 1995). Although algae are typically viewed as inhabiting a 2 -dimensional milieu

\footnotetext{
- Present address: Department of Marine Sciences, University of Puerto Rico - Mayagüez, Box 908, Lajas, Puerto Rico 00667,USA. E-mail: j_holmquist@rumac.upr.clu_edu
}

with space as a limiting resource (Dayton 1971, 1975 , McRoy \& Lloyd 1981), drift algae are an exception. Current-propelled clumps roll along the bottom (similar to tumbleweeds; Kilar \& Norris 1988, Holmquist 1994 ) and frequently settle in large accumulations (Gore et al. 1981, Virnstein \& Carbonara 1985, Olafsson 1988). The algae are patchily distributed (Virnstein \& Carbonara 1985, Herrnkind \& Butler 1986) and tend to occur in low-flow areas (Josselyn 1977, Kilar \& Norris 1988, Bell \& Hall 1997); accumulation in seagrass can be a function of seagrass patch size (Bell et al. 1995).

If a drifting algal patch is layered over the stationary seagrass structure, how is the latter affected? Dayton et al. (1984) described floating kelp plants creating gaps (canopy openings caused by mortality) in kelp-dominated assemblages. Several studies have suggested that increased macroalgal abundances associated with eutrophication are responsible for general seagrass declines (e.g. Guist \& Humm 1976, Shepherd et al. 1989, Valiela et al. 1992, den Hartog 1994). Such 
degradation could occur via production of anoxic conditions (Williams Cowper 1978, Norkko \& Bonsdorff 1996a), exploitation of dissolved gases or nutrient resources (Harlin \& Thorne-Miller 1981), shading (Fitzpatrick \& Kirkman 1995, Short et al. 1995), allelopathy (Fletcher 1975), or pH shifts (Wood 1972). However, seagrasses may have high resistance stability (sensu Dayton et al. 1984). The majority of seagrass biomass often lies within the substratum (Zieman 1982, Williams 1990). 'Root-biased' systems are relatively resistant to above-substratum disturbance (Pickett \& White 1985), and clonal plants, such as seagrasses, are adapted to dynamic environments (Caraco \& Kelly 1991). Thalassia testudinum, the dominant seagrass in the present study, has been shown to be resistant to natural disturbances (Burrell \& Schubel 1977. Birch \& Birch 1984), and it is primarily the above-ground biomass that is impacted by even severe hurricanes (Rogers et al. 1982).

Seasonally abundant drift algae tend to occur as mats in sheltered embayments, and these algae have been observed over unvegetated depressions (or 'blowouts'; Williams Cowper 1978, pers. obs.). Do drift algae simply accumulate over these blowouts because of hydrologic phenomena (Wood 1972, Williams Cowper 1978), or can the algae degrade the underlying seagrass structure and thus actually create gaps? My first objective in this investigation was to test whether shifting algae can modify configuration of stationary seagrass structure.

How is the assemblage of mobile fauna changed by vertical layering of macroalgal structure over that of seagrass? Sousa (1984) noted that the disturbance of sessile organisms is relatively well investigated but that effects on mobile animals are poorly understood. Restructuring of sessile communities may have severe indirect effects on mobile fauna (e.g. Onuf \& Quammen 1983, Schowalter 1985), because sessile organisms often provide primary habitat and food resources for mobile animals. If algal masses do degrade underlying seagrasses, the primary habitat of the majority of seagrass-associated species (e.g. Holmquist et al. 1989a, Heck \& Crowder 1991) woüld be removed. Further, the superimposed algae could produce anoxia (e.g. Valiela et al. 1992, Norkko \& Bonsdorff 1996a), interfere with larval settlement (Olafsson 1988, Bonsdorff et al. 1995) or feeding activities (Raffaeli et al. 1991), and affect fauna via production of secondary metabolites (Anéer 1987, Hay \& Fenical 1992). However, it is clear that algal structure, like that of seagrass, can harbor large assemblages of demersal fauna (Gore et al. 1981, Virnstein \& Howard 1987, Holmquist 1994 ) and enhance both refuge quality (Leber 1985. Duffy \& Hay 1991, Pohle et al. 1991) and food resources (Zimmerman et al. 1979, Hull 1987, Pohle et al. 1991) in a variety of ways. Algal masses accumulating over seagrass are likely to import fauna (Gore et al. 1981) that are carried with the tumbling algae (Holmquist 1994). Mobile fauna may preferentially exploit sessile organisms damaged by disturbance (Sousa 1984): litter from terrestrial plant perturbations can enhance some arthropod communities (Santos \& Whitford 1981, Seastedt \& Crossley 1981), and seagrass litter is an important resource for some animals inhabiting seagrass (Fenchel 1970, Sogard et al. 1987). My second objective was to test whether superimposition of algal structure over seagrass structure results in shifts in the faunal assemblage.

White \& Pickett (1985), drawing from Allen \& Starr (1982), emphasize that in considering potential disturbance, one must bear in mind the dimensions of a given community. In the seagrass-drift algal assemblage, the ratio of algal patch size to the size of the seagrass ramets or mobile invertebrates is high. An algal accumulation with an area of only $1 \mathrm{~m}^{2}$ is about $10^{4}$ times the basal area of a large seagrass shoot and about $10^{5}$ times the size of most associated animals. In this study, I test for effects of this scale of algal habitat addition on seagrasses and associated fauna.

\section{METHODS}

Study site. Field work was performed in shallow ( 2 to $3 \mathrm{~m}$ deep) seagrass beds in southwestern Florida Bay, Florida, USA. The seagrass meadows are composed of Thalassia testudinum (turtle grass), Halodule wrightii (shoal grass), and Syringodium filiforme (manatee grass) but are dominated by $T$. testudinum (area description in Holmquist et al. 1989b. Holmquist 1994). Sparse green algae, most commonly Caulerpa spp.. Halimeda spp., Penicillus spp. (shaving brush), and Udotea spp. (mermaid's fan), are interspersed beneath the seagrass canopy. Red and brown macroalgae occur year-round; Laurencia poiteaui is the most common species. The algae are initially attached to solid substrata (rubble, mollusc fragments, etc.), but masses often break free after reaching a size of about $25 \mathrm{~cm}$ diameter (pers. obs.). Drifting Laurencia spp. is particularly abundant in the area between late fall and early spring (Josselyn 1977), and accumulations of individual clumps form mats that usually range from 0.4 to $1 \mathrm{~m}$ in thickness. Mats usually remain intact and in place for about 6 mo after which time they senesce and decompose or break up and disperse (Josselyn 1977. Virnstein \& Carbonara 1985, Holmquist 1992).

Experimental protocol. I tested the null hypotheses of no effect of drift algal mats on underlying seagrass and no shifts in faunal assemblages by establishing (1) 12 manipulated algal mats over seagrass and (2) 12 
control seagrass plots. I later compared the 2 sets of plots for both seagrass and fauna. In order to reproduce the degree of shading found under naturally occurring algal mats, I measured photosynthetic photon flux fluence rate under 50 natural mats with a LiCor LI-188B radiometer/photometer and a Li-Cor LI$192 \mathrm{SB}$ underwater cosine sensor. The sensor was mounted at a $90^{\circ}$ angle to the main axis of a $3 \mathrm{~m}$ long PVC extension that was first used to position the sensor under the large mats without disturbing the algae, and then rotated $90^{\circ}$ to bring the sensor to an upright position perpendicular to the substrate. Less than $1 \%$ of the incident light present just above the algae penetrated the mats.

Experimental and control plots were established contemporaneously with natural mat accumulation and were located randomly throughout the 'Atlantic' subenvironment (Zieman et al. 1989) of Florida Bay, in locations not subject to major algal deposition. Each experimental plot was covered with $1 \mathrm{~m}^{2}$ of gathered Laurencia poiteaui. Underwater transport of the algae to the experimental plots removed some associated fauna as do naturally tumbling algae prior to coming to rest (Holmquist 1994), so some animals were carried to the plots with the algae, but there were fewer of these organisms carried to the experimental plots than are typically associated with stationary algal masses. I accumulated the gathered algae on each plot, over a period of $1 \mathrm{wk}$, to a thickness of $0.4 \mathrm{~m}$ and to the levels of algal density and light penetration (as measured by the radiometer/photometer) observed in natural mats. Algal canopy height was thus about $40 \mathrm{~cm}$ versus $18 \mathrm{~cm}$ for seagrass on the study plots. The masses of algae were secured over each experimental plot with sections of large mesh (15 cm square) thin plastic netting. I maintained algal densities on the experimental plots for the next 6 mo, after which time I removed the drift algal cover. Little additional algae (occasional clumps $<20 \mathrm{~cm}$ diameter) came to rest on the control and experimental plots.

Seagrass sampling. I sampled seagrass on control and experimental plots at the following times: (1) at the start of the experiment [immediately after initial faunal sampling (see below) and just before algal addition; $\mathrm{n}=12$ pairs of plots]; (2) after 6 mo of algal cover (immediately after faunal sampling and algal mat removal; $\mathrm{n}=12$ ); (3) 6 mo after algal removal (12 mo after the start of the experiment; $\mathrm{n}=5$ ); and (4) $18 \mathrm{mo}$ after algal removal (24 mo after the start of the experiment; $\mathrm{n}=5$ ). The latter 2 sampling periods had a reduced number of replicates due to loss of marker buoys. I used a randomly placed quadrat with an area of $185 \mathrm{~cm}^{2}$ for the initial sample from each plot. Short shoots (small, leaf-bearing shoots branching laterally from horizontal rhizomes; Zieman 1982) were pulled by hand to avoid initial damage to the rhizome layer. Samples were transported on ice to the laboratory where seagrass shoots of each species and green algal holdfasts were counted. The green, photosynthetic portions of all seagrass blades collected within each quadrat were washed in dilute $\mathrm{HCl}$ with gentle scraping (similar to recommended protocol of Dauby \& Poulicek 1995) to remove carbonate epiphytes and sediment and then dried at $95^{\circ} \mathrm{C}$ for $24 \mathrm{~h}$ to determine above-ground dry mass.

After the algal mats were removed from the experimental plots $(6 \mathrm{mo})$, I sampled all plots with a corer (185 $\mathrm{cm}^{2}$ sampling area). I used core samples, because I deemed the added information on below-ground biomass to outweigh damage to the plots at this stage of the experiment. I filled core holes with sediment. I discarded dead rhizomes and roots and washed living below-ground material with dilute $\mathrm{HCl}$, to help remove sediment, and then dried these components as above to calculate below-ground dry mass. Aboveground material was processed as before.

Sampling within each plot at the final 2 junctures was also random, with the exception of avoidance of positions of previous core samples. The third series of samples was again taken with the corer. Because I was concerned about cumulative coring impact to the plots, the fourth series was collected with the quadrat and hand gathering of only above-ground components.

Faunal sampling. I sampled the demersal fauna of each control and experimental plot immediately before construction of algal mats and 6 mo later, just before algal mats were removed. The animals associated with both seagrass and algae were sampled with throw traps (drop traps; i.e. boxes lacking a solid top or bottom that are cleared of fauna with nets). Throw traps have been used in a number of studies (e.g. Kushlan 1981, Huh 1984, Erwin et al. 1985, Kushlan et al. 1986, Sogard et al. 1987, 1989, Holmquist et al. $1989 \mathrm{a}, \mathrm{c})$ and have been shown to be highly efficient, relative to other collecting devices, for quantitatively sampling demersal organisms in vegetated habitats (Kushlan 1981, Freeman et al. 1984, Jacobsen \& Kushlan 1987, Rozas \& Minello 1997). Throw trapping of well-separated stations is effectively sampling with replacement (Jacobsen \& Kushlan 1987), and re-sampling seagrass-covered sites at 6 mo intervals over a period of 4 yr does not cause shifts in measures of seagrass cover or assemblages of mobile fauna (Holmquist unpubl.). However, throw trap sampling is highly disruptive to unvegetated mud bottoms (pers. obs. during work reported in Sogard et al. 1987, 1989, Holmquist et al. 1989a, c). Because throw trapping on the bare mud that remained on the plots after 6 mo of algal cover (see 'Results') would have greatly disrupted the seagrass recovery process, I opted not to 
collect fauna after the algal mats were removed and during gap recovery.

I used a device and protocol derived from that of Sogard et al. $(1987,1989)$ and Holmquist et al. $(1989 a$, c). The trap was a $0.5 \times 0.5 \mathrm{~m}$ box without a top or bottom and was constructed of sheet aluminum with a $0.5 \mathrm{~mm}$ square mesh screen secured over the top of the trap. The clearing device was a $0.5 \mathrm{~m}$ wide framed and handled net (bar seine) with $0.5 \mathrm{~mm}$ square mesh. Although published work to date records the use of throw traps in shallow water, the devices can be used below the surface as well. My protocol was as follows: I swam the trap to the plot to be sampled, free-dove with the apparatus to the bottom, and pushed the trap into the seagrass or sediment. An assisting scuba-diver then removed a screen covering the trap aperture and steadied the trap, while I made 1 sweep of the canopy with the bar seine. The scuba-diver replaced the top screen, while I ascended with the sample-containing bar seine. The net downward force of the water against the ascending net was sufficient to prevent the escape of demersal organisms from the bar seine. I then emptied the bar seine of animals, detritus, and algae into a water-filled container on the support boat. Ten such sweeps were performed for each plot. These techniques sample the demersal fauna of the seagrass or algal canopy but do not attempt to sample the sediment surface or highly mobile fishes. All algae were removed from traps on experimental plots at the end of the 6 mo period of algal cover and retained. A relatively inclusive group of major taxa, i.e. molluscs, decapods, stomatopods, asteroids, and ophiuroids, were identified to species level for most taxa; some taxa, for instance peracarids, were not considered. Algal samples were washed in dilute $\mathrm{HCl}$ prior to drying at $95^{\circ} \mathrm{C}$ for $24 \mathrm{~h}$ for determination of dry mass (for relation to animal abundances).

Analysis. I converted vegetation parameters to per $\mathrm{m}^{2}$ values to derive the corresponding dependent variables: seagrass standing crop $(=\mathrm{g}$ dry above-ground biomass $\mathrm{m}^{-2}$ ), seagrass shoots $\mathrm{m}^{-2}$ (total and for each species), $g$ dry below-ground biomass $\mathrm{m}^{-2}$, and green algal holdfasts $\mathrm{m}^{-2}$. Response vanables for mobile fauna were total individuals $\mathrm{m}^{-2}$, total individuals $\mathrm{g}^{-1}$ dry mass vegetation, and species richness. Cochran's tests (Underwood 1981, Kirk 1982, Day \& Quinn 1989) indicated minor to moderate heteroscedasticity for several variables. This heterogeneity of variance was best mitigated by $\sqrt{y}+\sqrt{y+1}$ (Freeman \& Tukey 1950, Kirk 1982) and $\log _{10}$ transformations for vegetation and faunal data, respectively. After transformation, minor heteroscedasticity remained for 2 variables. Following significant repeated measures ANOVAs, I therefore made comparisons with the Welch-Aspin $t$ test (Welch 1938, Aspin 1948) using Satterthwaite's degrees of freedom (Satterthwaite 1946), because this test is robust to unequal variances (Day \& Quinn 1989) with very little loss of power (Best \& Rayner 1987). Although seagrass might be resistant to disturbance, it seemed improbable that algal mats would benefit seagrasses; I used 1 -tailed tests for vegetation data. Directionality of effect for fauna was not predictable, so I used 2-tailed tests for these data. Although all tests were a priori orthogonal contrasts, I desired relatively tight control of type-1 error rate. I used the sequential Bonferroni adjustment (Holm 1979), which has greater power than the standard Bonferroni adjustment (Rice 1989), to correct probability values to familywise error rates. The families of contrasts were: all seagrass dependent variables, green algal density, and all dependent variables for mobile fauna. I provide both familywise and per contrast error rates.

\section{RESULTS}

\section{Seagrass}

Control and experimental plots did not differ significantly for any dependent variable prior to algal addition but were markedly different after algal addition. After 6 mo of algal cover, above-ground standing crop (Fig. 1A) and short shoot density (Fig. 1B) fell to about one-tenth of the levels of control plots and did not increase in the 6 mo following algal removal. After 18 mo of recovery, standing crop on the experimental plots was $29 \%$ of that on control plots but still differed significantly. Short shoots on experimental plots recovered to about half the density of the controls during this period. Below-ground biomass (Fig. 1C) on experimental plots was about one-half that of control plots after both 6 mo of algal cover and the ensuing 6 mo of recovery. Not a single green alga was quantified immediately after drift algal cover (Fig. 2). Green algae increased after 6 mo and reached $63 \%$ of control densities after 18 mo (not significant).

Most of the seagrass data are a function of Thalassia testudinum, because Syringodium filiforme and Halodule wrightii were comparatively sparse and patchily distributed. Although variance for the latter 2 species was high, there was some differential response among the 3 seagrasses. After 6 mo of algal cover, $T$. testudinum, $S$. filiforme, and $H$. wrightii fell to 12,4 , and $0 \%$ of their original densities, respectively ( $T$. testudinum: 762 to 95 ; S. filiforme: 231 to $9 ; H$. wrightii: 82 to 0 shoots $\mathrm{m}^{-2}$ ). After 18 mo of recovery, $T$. testudinum and S. filiforme increased to about one-quarter of onginal densities. $H$. wrightii, however, increased to 261 shoots $\mathrm{m}^{-2}(\mathrm{SE}=130)$ which was over 3 times the original density of this species and equal to $T$. testudinum density after $18 \mathrm{mo}$. 

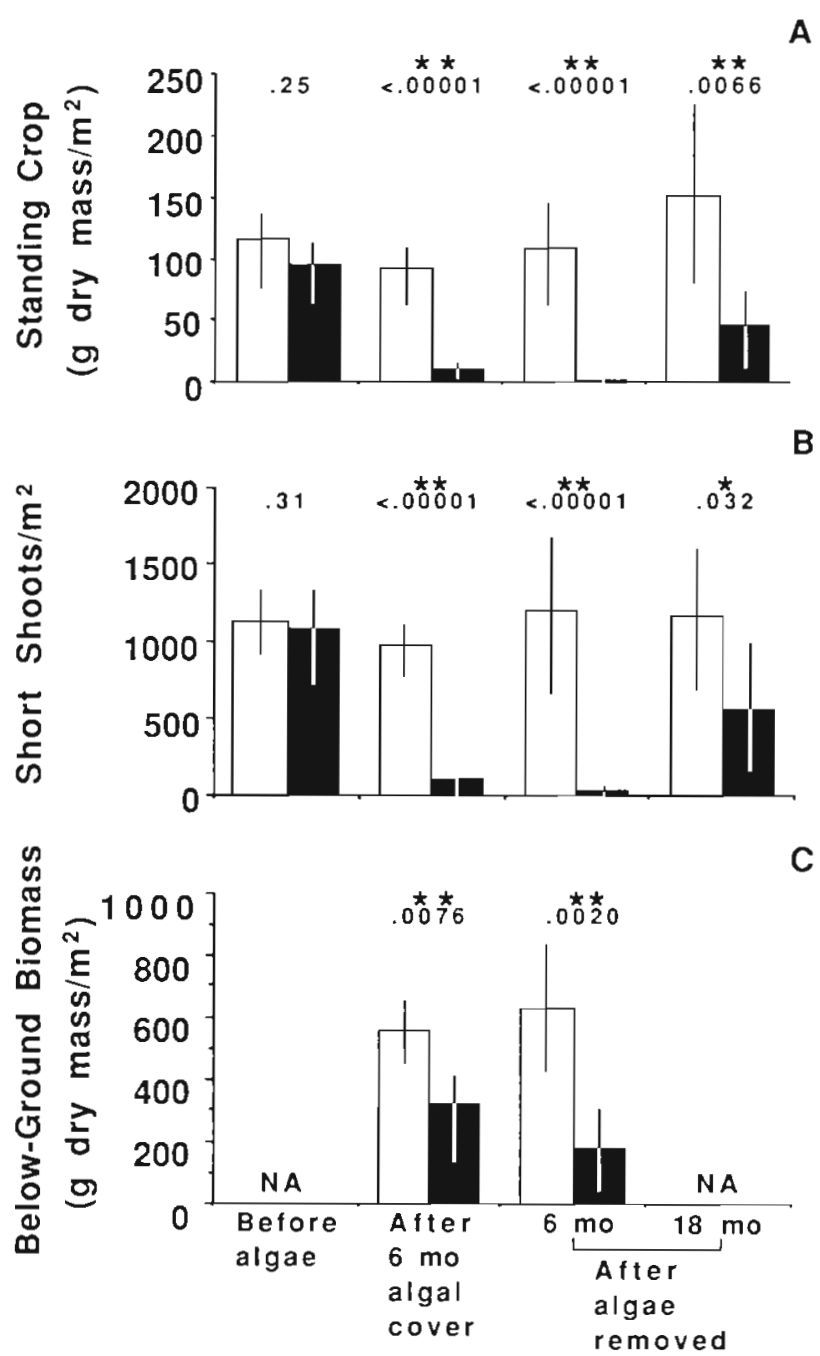

Fig. 1. Response of seagrass parameters to algal mat manipulations. (A) Standing crop. (B) shoot density, (C) below-ground biomass. Untransformed means on control ( $\square$ ) and experimental (a) plots are shown. NA: below-ground material was not collected during a given sampling series. Error bars are back-transformed $95 \%$ confidence intervals. *A difference between control and experimental plots which was significant at $\mathrm{p}<0.05$ following a 1 -tailed Welch-Aspin $t$ test. ${ }^{\star \star} \mathrm{A}$ difference that was also significant at $p<0.05$ following sequential Bonferroni correction to familywise error rate $(\mathrm{p}=0.033)$

\section{Mobile fauna}

Faunal abundance and species richness did not differ significantly between control and experimental plots before algal addition but diverged greatly during the experiment. Abundance of fauna on experimental plots increased after 6 mo of algal cover relative to abundance on control plots; this increase was by a factor of 6 when considered as a function of area (Fig. 3) or by a factor of 2 as a function of vegetation biomass (Fig. 4). Species richness was 4 times higher in the

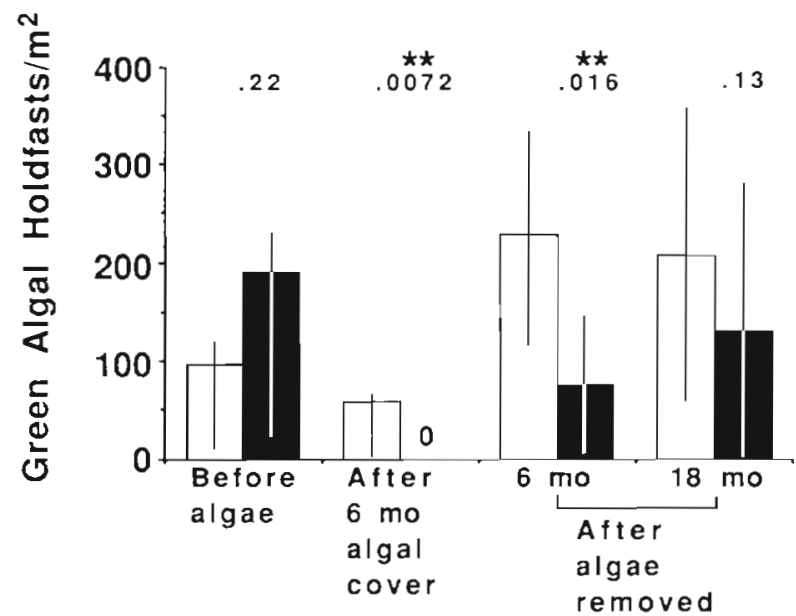

Fig. 2. Response of green algae (primarily Caulerpa, Halimeda, Penicillus, and Udotea) density to algal mat manipulations. Untransformed means on control ( $\square$ ) and experimental (-) plots are shown. Error bars as per Fig. 1. ${ }^{\star \star} A$ difference which was significant at $\mathrm{p}<0.05$ following sequential Bonferroni correction to familywise error rate $(p=0.048)$

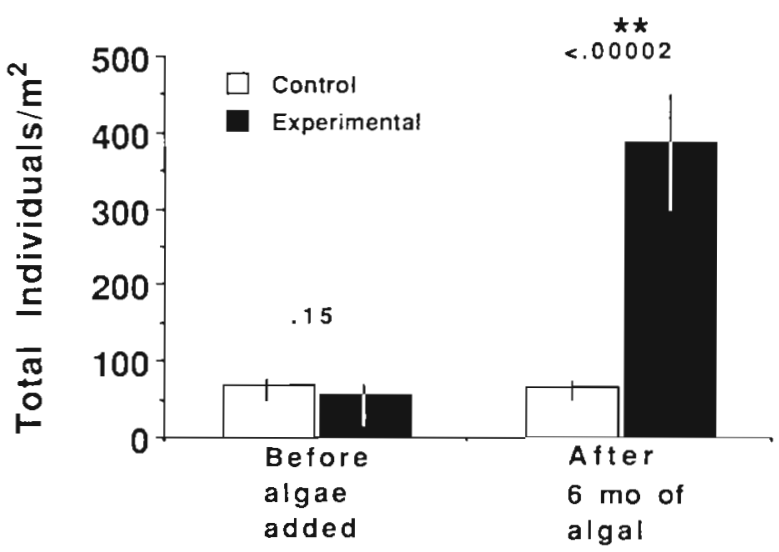

Fig. 3. Response of total individuals of canopy fauna $\mathrm{m}^{-2}$ to algal mat manipulations. Error bars as per Fig. 1 i tests were 2tailed. ${ }^{\star \star}$ A difference which was significant at $p<0.05$ following sequential Bonferroni correction to familywise error rate $(p=0.021)$

manipulated algal mats than in control seagrass plots (Fig. 5). My non-quantitative observations of plots in the months following algae removal revealed very few macrofauna on the denuded plots

There was also greater evenness in the canopy fauna of the algal plots, which contrasted with the high level of dominance apparent on control plots (Table 1). The caridean shrimp Thor floridanus accounted for $72.1 \%$ of the total seagrass fauna; no other species represented $>10 \%$ of the individuals quantified on control plots. In contrast, the dominant category for the algal 


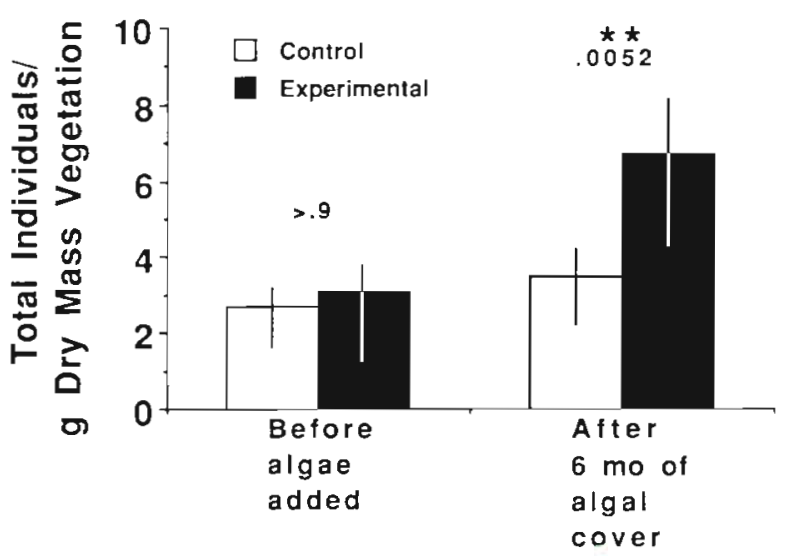

Fig. 4. Response of total individuals of canopy fauna $\mathrm{g}^{-1} \mathrm{dry}$ mass of vegetation to algal mat manipulations. Error bars and $\star \star$ as per Fig. 3

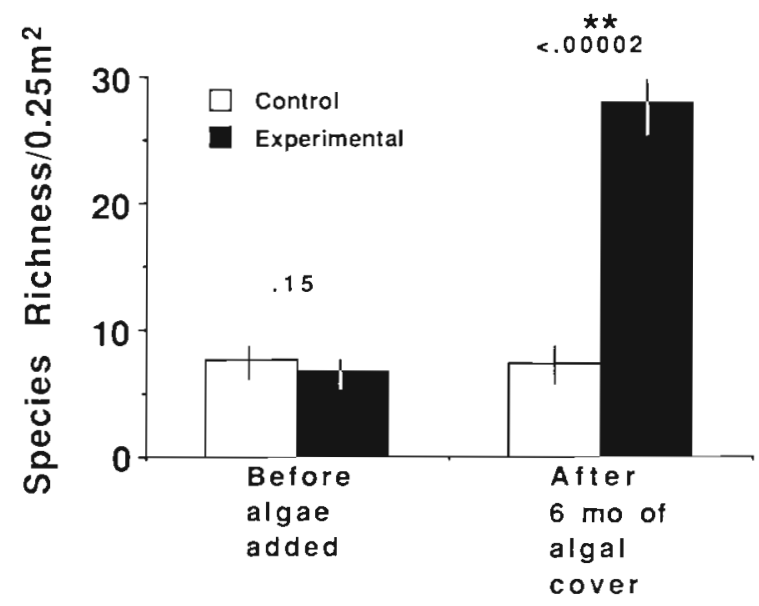

Fig. 5. Response of species richness of canopy fauna to algal mat manipulations. Error bars and ${ }^{\star \star}$ as per Fig. 3

mats was Ophiuroidea, comprising $37.8 \%$ of the fauna; even this level of dominance was lessened, because this category was a composite grouping of 7 species of brittlestars. Several non-ophiuroid species had relatively high abundance and less common species not presented in the table accounted for about $10 \%$ of the total individuals. Shrimps dominated the seagrass assemblage and comprised the 6 most common species and $93 \%$ of the total canopy fauna (Table 1). After algal cover, shrimps increased from 61 to 77 ind. $\mathrm{m}^{-2}$ but only represented $20 \%$ of the fauna. Thor floridanus and Periclimenes americanus increased in abundance, but Hippolyte pleuracanthus and Periclimenes iridescens were rare, and Latreutes fucorum, Tozeuma carolinense, and the commercial pink shrimp Penaeus duorarum were completely absent. Ophiuroids, crabs, gastropods, and bivalves were more common on the experimental, relative to the control, plots.

\section{DISCUSSION}

The superimposition of algal structure was a disturbance mechanism capable of opening sizable gaps in the seagrass canopy. Clarke \& Kirkman (1989) described 3 levels of perturbations in seagrass meadows: Type 1-partial leaf damage; Type 2-total leaf destruction; and Type 3-leaf, rhizome, and root loss. The drift algal accumulations caused all 3 levels of damage to underlying seagrass over 6 mo (probably earlier; pers. obs.). This level of destruction occurred despite mitigation of stress via support of stressed by unstressed ramets (Tomasko \& Dawes 1989) and reserves in the rhizome mat. Pickett \& White (1985) suggest that root-biased systems are resistant to above-substratum disturbances, and seagrass meadows are decidedly root-biased. In south Florida, only 15 to $20 \%$ of total Thalassia testudinum biomass is comprised of seagrass blades (Zieman 1982), and roots and rhizomes accounted for about $84 \%$ of the total in

Table 1. Most common constituents of control seagrass plots and manipulated algal plots after 6 mo, given as number $\mathrm{m}^{-2}$ and percentage of total individuals collected for each treatment

\begin{tabular}{|c|c|c|}
\hline & No. $\mathrm{m}^{-2}$ & $\%$ \\
\hline \multicolumn{3}{|l|}{ Seagrass } \\
\hline Thor floridanus Caridean shrimp & 47.6 & 72.1 \\
\hline Periclimenes americanus Caridean shrimp & 4.8 & 7.2 \\
\hline Hippolyte pleuracanthus Caridean shrimpd & 3.2 & 4.9 \\
\hline Latreutes fucorum Caridean shrimp & 2.3 & 3.5 \\
\hline Periclimenes iridescens Caridean shrimp & 1.9 & 2.9 \\
\hline Penaeus duorarum Penaeid shrimp & 0.9 & 1.4 \\
\hline Mitrella argus Gastropod & 0.7 & 1.0 \\
\hline Modulus modulus Gastropod & 0.7 & 1.0 \\
\hline Astraea americana Gastropod & 0.5 & 0.8 \\
\hline Tozeuma carolinense Caridean shrimp & 0.4 & 0.6 \\
\hline Other & 3.1 & 4.7 \\
\hline \multicolumn{3}{|l|}{ Algal mats } \\
\hline Ophiuroidea (>7 spp.) Brittlestars ${ }^{b}$ & 147.0 & 37.8 \\
\hline Thor floridanus Caridean shrimp & 65.5 & 16.8 \\
\hline Paguristes tortugae Hermit $\mathrm{crab}^{c}$ & 47.2 & 12.1 \\
\hline Astraea americana Gastropod & 30.4 & 7.8 \\
\hline Tegula fasciata Gastropod & 14.0 & 3.6 \\
\hline Argopecten nucleus Bivalve & 1.1 .7 & 3.0 \\
\hline Mitrella argus Gastropod & 10.4 & 2.6 \\
\hline Periclimenes americanus Caridean shrimp & 7.8 & 2.0 \\
\hline Pagurus mclaughlinae Hermit crab & 7.4 & 1.9 \\
\hline Neopanope packardii Mud crab & 7.0 & 1.8 \\
\hline Other & 41.3 & 10.6 \\
\hline \multicolumn{3}{|c|}{$\begin{array}{l}\text { "See Gore et al. (1981) for discussion of } H \text { pleuracanthus- } \\
\text { zostericola complex }\end{array}$} \\
\hline \multicolumn{3}{|c|}{$\begin{array}{l}{ }^{b} \text { Ophiopsila risei and Ophionereis olivacea were the most } \\
\text { abundant brittlestars }\end{array}$} \\
\hline \multicolumn{3}{|c|}{$\begin{array}{l}\text { 'Paguristes tortugae should be viewed as a species com- } \\
\text { plex pending further systematic work (P. McLaughin } \\
\text { pers. comm.) }\end{array}$} \\
\hline
\end{tabular}


the meadows used in this study (Holmquist 1992). The below-ground component can reach $98 \%$ of total biomass in some systems (Williams 1990). Nevertheless, superimposed algae did cause extensive damage to this heavily root-biased meadow; the above-ground disturbance was sufficiently intense to damage the root-rhizome mat, a prerequisite for substantial alteration of such a system (Pickett \& White 1985).

Although algal mats destroyed the primary structure utilized by seagrass-associated fauna on the experimental plots, the superimposed algae provided alternative structure that supported a highly abundant and species-rich assemblage of animals. Many of these species were present in seagrass as well (see also Virnstein \& Howard 1987) but in lower numbers and with less regular occurrence. The high level of abundance and richness on the experimental plots was similar to that observed in naturally occurring algal mats and was maintained despite fairly low mean and minimum levels of dissolved oxygen (Holmquist 1992). In a study investigating effects of ice scour on the seagrass Zostera marina and associated fauna, Schneider \& Mann (1991) found faunal abundances to rebound much more quickly than seagrass cover and attributed the rapid faunal recovery to growth of algae on the disturbed substrate. In my study, species that increased in abundance may have benefited from inherent characteristics of the algal mats such as provision of refuge from predation, enhanced food resources, or differential recruitment (e.g. Leber 1985, Eckman 1987, Duffy \& Hay 1991, Pohle et al. 1991). Some animals were transported to the site with the accumulated algae, as is the case with naturally deposited algae (Holmquist 1994), and some of these fauna (or progeny thereof in the case of brooders) may have still been associated with the algal mats when they were sampled 6 mo after construction. Alternatively, other species may have benefited specifically from interaction of the algae with the seagrasses, particularly from increased production of seagrass detritus (an important resource for some seagrass fauna; Fenchel 1970, Sogard et al. 1987). Lastly, some species may have seemed to increase in abundance as a result of sampling in 2 different habitats. Sampling devices are rarely equally efficient on differing substrata, and some taxa, particularly molluscs, might be more easily captured in algae than in seagrass.

Some taxa, particularly shrimps, were conspicuously reduced in proportion in the algal mats. However, 2 common shrimps, Thor floridanus and Periclimenes americanus, increased in abundance, and Virnstein \& Howard (1987) found crustaceans to be more abundant in clumps of algae than in seagrass. Positive responses of other taxa to algal mats, rather than negative responses by shrimps, may have led to the observed proportional decrease in shrimp abundance. Nevertheless, several shrimp species present in the control seagrass were rare or absent in the macroalgal mats. Further, Holmquist (1994) found an average of 83 shrimps in small (25 cm diameter) algal clumps isolated in these seagrass beds. If abundance of shrimps increased linearly with additional volume of algal habitat, there should be well over 1000 shrimps $\mathrm{m}^{-2}$ algal mat rather than the observed 77 shrimps. This non-linearity in response to increased patch scale (see also Bell et al. 1995) suggests that shrimp could suffer disproportionately from the negative factors associated with algal mats (see 'Introduction'); for instance, these small natant species may be more susceptible to lower oxygen levels than more sedentary crabs, molluscs, and echinoderms.

Is an overlay of algal structure a source of disturbance for mobile fauna in grassbeds? With regard to the effect on fauna inhabiting seagrass structure that is newly covered by an algal mat, the answer is equivocal. Direct mortality is unlikely as algae accumulate a few clumps at a time; rather, small tumbling clumps harbor organisms (Holmquist 1994) and are likely to contribute animals to a local assemblage as the algae accumulate. Some species, including several shrimps, are probably reduced in proportion by slow emigration as the mat accumulates and the habitat changes. However, increased immigration of adults or recruitment of other taxa appear to more than compensate for the loss of overall abundance and biomass associated with reductions in some populations. The system does not appear to meet a commonly used criterion for disturbance effects: removal of biomass (Grime 1977). However, in a broader sense perturbation did occur: there was a deviation in a component of the ecological system (Rykiel 1985) and a disruption of community structure and change in resources (White \& Pickett 1985). Although increased species richness of fauna was associated with a newly accumulated algal mat, it is unlikely that this increased diversity is a function of relaxation of pressure from competitive dominants as seen in other systems (e.g. Connell 1978, Sousa 1979). Drift algae provided a highly complex structure for fauna even as the mat destroyed the primary seagrass structure typically utilized by some of these animals. As Thistle (1981) and Van Blaricom (1982) suggested for other systems, it is probable that this provision of resources, rather than reduced competition, is responsible for the observed positive response of fauna

Raffaelli et al. (1989) and Norkko \& Bonsdorff (1996b) hypothesized that small mats of algae would have minimal negative, and possible positive, effects on underlying soft-substrate fauna but that contiguous mats would be detrimental. The same is probably true in the seagrass-macroalgal mosaic. Small algal patches 
not coalesced into large mats do not kill underlying seagrass and are beneficial to fauna (Coen et al. 1981, Heck \& Thoman 1981, Leber 1985). As an example, Holmquist $(1992,1994)$ found $25 \mathrm{~cm}$ diameter algal clumps to contain 2.3 and 7.5 times the number of epifauna as seagrass and sand, respectively, on a per unit area basis. The present study shows that larger mats can aiso support a high species richness and abundance of fauna, but the structural complexity provided by these larger Laurencia spp. mats is likely to be mitigated by ephemerality as Wilson et al. (1990) and Sogard \& Able (1991) found for mats of the green alga Ulva lactuca. Laurencia spp. mats formed by drifting algae only persist for a period of months (Josselyn 1977, Virnstein \& Carbonara 1985, Holmquist 1992); as the mats break up, structure for mobile fauna disappears. Even if a patch accumulates algal structure annually, the underlying gap exists in an unvegetated state during the balance of the year, during which time seagrass recovery progresses slowly (this study). Moreover, in addition to being ephemeral, the large algal patches degrade underlying seagrass structure. Although the high complexity of large mats formed by drifting algae augmented habitat for mobile fauna on a short temporal scale, longer-term effects on fauna are probably negative due to mat ephemerality and degradation of the less-complex, but consistently present, seagrass structure.

Acknowledgements. L. Abele, W. Herrnkind, F. James, D. Meeter, J. Schmidt-Gengenbach, T. Miller, R. Livingston, W. Tschinkel, S. Williams, P. Yoshioka, and anonymous reviewers took time to critique various stages of the manuscript. I benefited from discussions with D. Burr, T. Burr, F. Jordan, D Simberloff, and A. Winn. K. Hainge helped in the field, and W. Herrnkind, J. Hunt, R. Livingston, G. Powell, M. Robblee, D. Smith, and G. Stanton all kindly loaned equipment. I thank R. Durner, B. Gibbs, J. Ogden, and J. Swanson for hosting me at the Florida Keys Marine Laboratory. Representative specimens of some species were graciously identified by $W$. Lyons (molluscs) and G. Hendler and C. Pomeroy (brittlestars). I thank J. Schmidt-Gengenbach for data entry. Support was provided by the Lemer-Gray Fund, the Menzel Memorial Fund, Sigma Xi, the Jacobson Fund, the Florida Institute of Oceanography, and the FSU Department of Biological Science.

\section{LITERATURE CITED}

Allen TFH, Starr TB (1982) Hierarchy: perspectives for ecological complexity. University of Chicago Press, Chicago

Anéer G (1987) High natural mortality of Baltic herring (Clupea harengus) eggs caused by algal exudates? Mar Biol 94:163-169

Aspin AA (1948) An examination and further development of a formula arising in the problem of comparing two mean values. Biometrika 35:88-96

Bell SS, Hall MO (1997) Drift macroalgal abundance in seagrass beds: investigating large-scale associations with physical and biotic attributes. Mar Ecol Prog Ser 147: $277=283$

Bell SS, Hall MO, Robbins BD (1995) Toward a landscape approach in seagrass beds: using macroalgal accumulation to address questions of scale. Oecologia 104:613-618

Best DJ, Rayner JCW (1987) Welch's approximate solution for the Behrens-Fisher problem. Technometrics 29:205-210

Birch WR, Birch M (1984) Succession and pattern of tropical intertıdal seagrasses in Cockle Bay, Queensland, Australia: a decade of observations. Aquat Bot 19:343-367

Bonsdorff E, Norkko A, Boström C (1995) Recruitment and population maintenance of the bivalve Macoma balthica (..) - factors affecting settling success and early survival on shallow sandy bottoms. Proc 28th Eur Mar Biol Symp. Olsen \& Olsen, Fredensborg, p 253-260

Burrell DC, Schubel JR (1977) Seagrass ecosystem oceanography. In: McRoy $\mathrm{CP}$, Helfferich $\mathrm{C}$ (eds) Seagrass ecosystems: a scientific perspective. Dekker, New York, p 195-232

Caraco T, Kelly CK (1991) On the adaptive value of physiological integration in clonal plants. Ecology 72:81-93

Clarke SM, Kirkman H (1989) Seagrass dynamics. In: Larkum AWD, McComb AJ, Shepherd SA (eds) Biology of seagrasses: a treatise on the biology of seagrasses with special reference to the Australian region. Elsevier, Amsterdam, p 304-345

Coen LD, Heck KL Jr, Abele LG (1981) Experiments on competition and predation among shrimps of seagrass meadows. Ecology 62:1484-1493

Connell JH (1978) Diversity in tropical rain forests and coral reefs. Science 199:1302-1310

Dauby P, Poulicek M (1995) Methods for removing epiphytes from seagrasses: SEM observations on treated leaves. Aquat Bot 52:217-228

Day RW, Quinn GP (1989) Comparisons of treatments after an analysis of variance in ecology. Ecol Monogr 59:433-463

Dayton PK (1971) Competition, disturbance, and community organization: the provision and subsequent utilization of space in a rocky intertidal community. Ecol Monogr 41 $351-389$

Dayton PK (1975) Environmental evaluation of ecological dominance in a rocky intertidal algal community. Ecol Monogr 45:137-159

Dayton PK, Currie V, Gerrodette T, Keller BD, Rosenthal R, Ven Tresca D (1984) Patch dynamics and stability of some California kelp communities. Ecol Monogr 54:253-289

den Hartog C (1994) Suffocation of a littoral Zostera bed by Enteromorpha radiata. Aquat Bot 47:21-28

Duffy JE, Hay ME (1991) Food and shelter as determinants of food choice by an herbivorous marine amphipod. Ecology $72: 1286-1298$

Eckman JE (1987) The role of hydrodynamics in recruitment, growth, and survival of Argopecten irradians (L.) and Anomia simplex (D'Orbigny) within eelgrass meadows. J Exp Mar Biol Ecol 106:165-191

Erwin RM, Hafner H, Dugan P (1985) Differences in the feedung behavior of little egrets (Egretta garzetta) in two habitats in the Camargue, France. Wilson Bull 97:534-538

Fenchel I (1.970) Studies on the decomposition of organic detritus derived from the turtle grass Thalassia testudinum. Limnol Oceanogr 15:14-20

Fitzpatrick J, Kirkman. H (1995) Effects of prolonged shading stress on growth and survival of seagrass Posidonia aus. tralis in Jervis Bay, New South Wales, Australia. Mar Ecol Prog Ser 127:279-289

Fletcher RL (1975) Heteroantagonism observed in mixed algal cultures. Nature 253:534-535 
Forman RTT (1995) Land mosaics: the ecology of landscapes and regrons. Cambridge University Press, Cambridge

Freeman BJ, Greening HS, Oliver JD (1984) Comparisons of three methods of sampling fishes and macroinvertebrates in a vegetated freshwater wetland. J Freshwat Ecol 2: $603-610$

Freeman MF, Tukey JW (1950) Transformations related to the angular and the square root. Ann Math Statist 21:607-611

Gore RH, Gallaher EE, Scotto LE, Wilson KA (1981) Studies on decapod Crustacea from the Indian River Region of Florida. XI. Community composition, structure, biomass and species-areal relationships of seagrass and drift-algae associated macrocrustaceans. Estuar Coast Shelf Sci 12: $485-508$

Grume JP (1977) Evidence for the existence of three primary strategies in plants and its relevance to ecological and evolutionary theory. Am Nat 111:1169-1194

Guist GG Jr, Humm HJ (1976) Effects of sewage effluent on growth of Ulva lactuca. Fla Sci 4:267-272

Harlin MM, Thorne-Miller B (1981) Nutrient enrichment of seagrass beds in a Rhode Island coastal lagoon. Mar Biol 65:221-229

Hay ME, Fenical W (1992) Chemical mediation of seaweedherbivore interactions. In: John DM, Hawkins SJ, Price JH (eds) Systematics Assoc Spec Vol No 46. Clarendon, Oxford, p 319-337

Heck KL Jr, Crowder LB (1991) Habitat structure and predator-prey interactions in vegetated aquatic systems. In: Bell SS, McCoy ED, Mushinsky HR (eds) Habitat structure: the physical arrangement of objects in space. Chapman and Hall, London, p 281-299

Heck KL Jr, Thoman TA (1981) Experiments on predator-prey interactions in vegetated aquatic habitats. J Exp Mar Biol Ecol 53:25-134

Herrnkind WF, Butler MJ IV (1986) Factors regulating postlarval settlement and juvenile microhabitat use by spiny lobsters Panulirus argus. Mar Ecol Prog Ser 34:24-30

Holm S (1979) A simple sequentially rejective multiple test procedure. Scand J Statist 6:65-70

Holmquist JG (1992) Disturbance, dispersal, and patch insularity in a marine benthic assemblage: influence of a mobile habitat on seagrasses and associated fauna. PhD dissertation, Florida State University, Tallahassee

Holmquist JG (1994) Benthic macroalgae as a dispersal mechanism for fauna: influence of a marine tumbleweed. J Exp Mar Biol Ecol 180:235-251

Holmquist JG, Powell GVN, Sogard SM (1989a) Decapod and stomatopod assemblages on a system of seagrass-covered mud banks in Florida Bay. Mar Biol 100:473-483

Holmquist JG, Powell GVN, Sogard SM (1989b) Sediment, water level and water temperature characteristics of Florida Bay's grass-covered mudbanks. Bul] Mar Sci 44 348-364

Holmquist JG, Powell GVN, Sogard SM (1989c) Decapod and stomatopod communities of seagrass-covered mud banks in Florida Bay: inter-and intra-bank heterogeneity with special reference to isolated subenvironments. Bull Mar Sci 44:251-262

Huh SH (1984) Seasonal varlations in populations of small fishes concentrated in shoalgrass and turtlegrass meadows. J Oceanol Soc Korea 19:44-55

Hull SC (1987) Macroalgal mats and species abundance: a field experiment. Estuar Coast Shelf Sci 25:519-532

Ims RA (1995) Movement patterns related to spatial structures. In: Hansson L, Fahrig L, Merriam G (eds) Mosaic landscapes and ecological processes. Chapman and Hall, London, p 85-109
Jacobsen T, Kushlan JA (1987) Sources of sampling bias in enclosure fish trapping: effects on estimates of density and diversity. Fish Res 5:401-412

Josselyn MN (1977) Seasonal changes in the distribution and growth of Laurencia poitej (Rhodophyceae, Ceramiales) in a subtropical lagoon. Aquat Bot 3:217-229

Kilar JA, Norris JN (1988) Composition, export, and import of drift vegetation on a tropical, plant-dominated, fringing-reef platform (Caribbean Panama). Coral Reefs 7: 93-103

Kirk RE (1982) Experimental design: procedures for the behavioral sciences. Brooks/Cole Publishing Co., Monterey

Kushlan JA (1981) Sampling characteristics of enclosure fish traps. Trans Am Fish Soc 110:557-562

Kushlan JA, Voorhees SA, Loftus WF, Frohring PC (1986) Length, mass, and calorific relationships of Everglades animals. Fla Sci 49:65-79

Leber KM (1985) The influence of predatory decapods, refuge, and microhabitat selection on seagrass communities. Ecology 66:1951-1964

MCRoy CP, Lloyd DS (1981) Comparative function and stability of macrophyte-based systems. In: Longhurst AR (ed) Analysis of marine ecosystems. Academic Press, London, p $473-489$

Norkko A, Bonsdorff E (1996a) Rapid zoobenthic community responses to accumulations of drifting algae. Mar Ecol Prog Ser 131:143-157

Norkko A, Bonsdorff E (1996b) Population responses of coastal zoobenthos to stress induced by drifting algal mats. Mar Ecol Prog Ser 140:141-151

Olafsson EB (1988) Inhibition of larval settlement to a soft bottom benthıc community by drifting algal mats: an experimental test. Mar Biol 97:571-574

Onuf CP, Quammen ML (1983) Fishes in a California coastal lagoon: effects of major storms on distribution and abundance. Mar Ecol Prog Ser 12:1-14

Pickett STA, White PS (1985) Patch dynamics: a synthesis. In: Pickett STA, White PS (eds) The ecology of natural disturbance and patch dynamics. Academic Press, San Diego, p $371-384$

Pohle DG, Bricelj VM, Garcia-Esquivel Z (1991) The eelgrass canopy: an above-bottom refuge from benthic predators for juvenile bay scallops Argopecten irradians. Mar Ecol Prog Ser 74:47-59

Raffaelli D, Hull S, Milne H (1989) Long-term changes in nutrients, weed mats and shorebirds in an estuarine system. Cah Biol Mar 30:259-270

Raffaelli D, Limia J, Hull S, Pont S (1991) Interactions between the marne amphipod Corophium volutator and macroalgal mats on estuarine mudflats. J Mar Biol Assoc UK 71:899-908

Rice WR (1989) Analyzing tables of statistical tests. Evolution 43:223-225

Rogers CS, Suchanek TH, Pecora FA (1982) Effects of hurricanes David and Frederic (1979) on shallow Acropora palmata reef communities: St. Croix, U.S. Virgin lslands. Bull Mar Sci 32:532-548

Rozas LR, Minello TJ (1997) Estimating densities of small fishes and decapod crustaceans in shallow estuarine habitats: a review of sampling design with focus on gear selection. Estuaries 20:199-213

Rykiel EJ Jr (1985) Towards a definition of ecological disturbance. Aust J Ecol 10:361-365

Santos PF, Whitford WG (1981) The effects of microarthropods on litter decomposition in a Chihuahuan desert ecosystem. Ecology 62:654-663 
Satterthwaite FE (1946) An approximate distribution of estimates of variance components. Biometrics Bull 2: $110-114$

Schneider FI, Mann KH (1991) Rapid recovery of fauna following simulated ice rafting in a Nova Scotian seagrass bed. Mar Ecol Prog Ser 78:57-70

Schowalter TD (1985) Adaptations of insects to disturbance. In: Pickett STA, White PS (eds) The ecology of natural disturbance and patch dynamics. Academic Press, San Diego, p 235-252

Seastedt TR. Crossley DA Jr (1981) Microarthropod response following cable logging and clear-cutting in the southern Appalachians. Ecology 62:126-135

Shepherd SA, McComb AJ, Bulthuis DA, Neverauskas V, Steffensen DA, West R (1989) Decline of seagrasses. In: Larkum AWD, McComb A.J, Shepherd SA (eds) Biology of seagrasses: a treatise on the biology of seagrasses with special reference to the Australian region. Elsevier, Amsterdam, p 346-393

Short FT, Burdick DM, Kaldy JE III (1995) Mesocosm experiments quantify the effects of eutrophication on eelgrass. Zostera marina. Limnol Oceanogr 40:740-749

Sogard SM, Able KW (1991) A comparison of eelgrass, sea lettuce macroalgae, and marsh creeks as habitats for epibenthic fishes and decapods. Estuar Coast Shelf Sci 33: 501-519

Sogard SM, Powell GVN, Holmquist JG (1987) Epibenthic fish communities on Florida Bay banks: relations with physical parameters and seagrass cover. Mar Ecol Prog Ser 40:25-39

Sogard SM, Powell GVN, Holmquist JG (1989) Spatial distribution and trends in abundance of fishes residing in seagrass meadows on Florida Bay mudbanks. Bull Mar Sci 44: $179-199$

Sousa WP (1979) Disturbance in marine intertidal boulder fields: the nonequilibrium maintenance of species diversity. Ecology 60:1225-1239

Sousa WP (1984) The role of disturbance in natural communities. Annu Rev Ecol Syst 15:353-391

Stamps JA, Buechner M, Krishnan VV (1987) The effects of edge permeability and habitat geometry on emigration from patches of habitat. Am Nat 129:533-552

Thistle D (1981) Natural physical disturbances and communities of marine soft bottoms. Mar Ecol Prog Ser 6:223-228

Tomasko DA, Dawes CJ (1989) Evidence for physiological integration between shaded and unshaded short shoots of Thalassia testudinum. Mar Ecol Prog Ser 54:299-305

Underwood AJ (1981) Techniques of analysis of variance in experimental marine biology and ecology. Oceanogr Mar Biol Annu Rev 19:513-605

Valiela I, Foreman $\mathrm{K}$, LaMontagne $M$, Hersh D, Costa J, Peckol P, DeMeo-Andreson B, D'Avanzo C. Babione M.

Editorial responsibility: Kenneth Heck, Jr (Contributing

Editor), Dauphin Island, Alabama, USA
Sham CH, Brawley J, Lajtha K (1992) Couplings of watersheds and coastal waters: sources and consequences of nutrient enrichment in Waquolt Bay, Massachusetts. Estuaries $15: 443-457$

Van Blaricom GR (1982) Experimental analyses of structural regulation in a marine sand community exposed to oceanic swell. Ecol Monogr 52:283-305

Virnstein RW, Carbonara PA (1985) Seasonal abundance and distribution of drift algae and seagrasses in the mid-Indian River Lagoon, Florida. Aguat Bot 23:67-82

Virnstein RW, Howard RK (1987) Motile epifauna of marine macrophytes in the Indian River Lagoon, Florida. II. Comparisons between drift algae and three species of seagrasses. Bull Mar Sci 41:13-26

Welch BL (1938) The significance of the difference between two means when the population variances are unequal. Biometrika 29:350-362

White PS, Pickett STA (1985) Natural disturbance and patch dynamics: an introduction. In: Pickett STA, White PS (eds) The ecology of natural disturbance and patch dynamics Academic Press, San Diego, p 3-16

Wiens JA (1992) Ecological flows across landscape boundaries: a conceptual overview. In: Hansen AJ, di Castri $F$ (eds) Landscape boundaries: consequences for biotic diversity and ecological flows. Springer-Verlag, New York, p 217-235

Wiens JA, Crawford CS, Gosz JR (1985) Boundary dynamics: a conceptual framework for studying landscape ecosystems. Oikos 45:421-427

Williams SL (1990) Experimental studies of Caribbean seagrass bed development. Ecol Monogr 60:449-469

Williams Cowper S (1978) The drift algae community of seagrass beds in Redfish Bay, Texas. Contrib Mar Sci 21: $125-132$

Wilson KA, Able KW, Heck KL Jr (1990) Predation rates on juvenile blue crabs in estuarine nursery habitats: evidence for the importance of macroalgae (Ulva lactuca). Mar Ecol Prog Ser 58:243-251

Wood EJF (1972) Unicellular plants. In: Kinne O (ed) Marine ecology. A comprehensive, integrated treatise on life in oceans and coastal waters. Vol 1, Environmental factors, Part 3. Wiley, New York, p 1272-1276

Zieman JC (1982) The ecology of the seagrasses of south Florida: a community profile. Publication FWS/OBS82/25, US Fish and Wildlife Services, Office of Biological Services, Washington, DC

Zieman JC. Fourqurean JW, Iverson RL (1989) Distribution abundance and productivity of seagrasses and macroalgae in Florida Bay. Bull Mar Sci 44:292-311

Zimmerman R, Gibson R, Harrington J (1979) Herbivory and detritivory among gammaridean amphipods from a Florida seagrass community. Mar Biol 54:41-47

Submitted: March 28, 1997; Accepted: September 4, 1997 Proofs received from author(s): Ociober 31, 1997 